Agro-Science Journal of Tropical Agriculture, Food, Environment and Extension Volume 17 Number 3 (September 2018) pp. 16-21

ISSN 1119-7455

\title{
THE EFFECT OF NATURAL AND ARTIFICIAL PRESERVATIVES AND STORAGE TEMPERATURE ON THE PH AND MICROBIAL LOAD OF FRESHLY PRODUCED APPLE (Malus domestica) JUICE
}

\author{
${ }^{* 1}$ Ekanem J.O. and ${ }^{2}$ Ekanem O.O. \\ ${ }^{1}$ Department of Microbiology, University of Uyo, Akwa Ibom State, Nigeria \\ ${ }^{2}$ Department of Food Science and Technology, University of Uyo, Akwa Ibom State, Nigeria \\ Corresponding author's email: johnnykoko01@yahoo.com
}

\begin{abstract}
Apple (Malus domestica) juice was treated with $0.5 \mathrm{~g} / \mathrm{ml}$ garlic, $0.5 \mathrm{~g} / \mathrm{ml}$ ginger, $0.25 \mathrm{~g} / \mathrm{ml}$ mix of ginger and garlic and $0.05 \%(w / v)$ of sodium benzoate respectively where the ginger, garlic and sodium benzoate serves as natural and artificial preservatives. Their effects on the apple fruit juice were evaluated during 8 days of storage at $4^{\circ} \mathrm{C}$ and at room temperature $\left(28 \pm 2^{\circ} \mathrm{C}\right)$. The microbial counts ranged from $4.0 \times 10^{4}$ to $7.0 \times 10^{3}$ cfu/ml and from $1.0 \times 10^{4}$ to $2.0 \times 10^{3} \mathrm{cfu} / \mathrm{ml}$ for bacteria and fungi, respectively in the samples treated with ginger, garlic and sodium benzoate and from $1.2 \times 10^{4}$ to $2.2 \times 10^{4} \mathrm{cfu} / \mathrm{ml}$ in the apple juice without treatment. Juice treated with sodium benzoate had the least microbial contamination while the untreated juice had the highest. There was marginal decrease in $\mathrm{pH}$ values across treatments in stored apple juice with juice stored at $4^{\circ} \mathrm{C}$ showing the least change in $\mathrm{pH}$ compared to that stored at room temperature. The results obtained show that the preservatives exhibited antimicrobial effect on the microbial load and that $\mathrm{pH}$ has a significant impact on the shelf-life of the fruit juice as the microbial load was least when stored at low temperature the pH as acidity tends to be inclined towards low $\mathrm{pH}$.
\end{abstract}

Key words: apple juice, $\mathrm{pH}$, microbial load, sodium benzoate, temperature

\section{INTRODUCTION}

The apple tree (Malus domestica) is a deciduous tree in the rose family best known for its sweet, pomaceous fruit, the apple(GRIN, 2012) and stands 1.8 to $4.6 \mathrm{~m}$ (6 to $15 \mathrm{ft})$ tall in cultivation and up to $39 \mathrm{ft}(12 \mathrm{~m})$ in the wild (GRIN, 2012). It is cultivated worldwide as a fruit tree, and is the most widely grown species in the genus Malus. About 80 million tons of apples were grown worldwide in 2013, and China produced almost half of this total (FAO, 2015). The United States is the secondleading producer, with more than $6 \%$ of world production. Apples are often eaten raw but can also be found in many prepared foods (especially desserts) and drinks. The fruit matures in late summer or autumn, and varieties exist with a wide range of sizes. Commercial growers aim to produce an apple that is 7.0 to $8.3 \mathrm{~cm}$ (2.75 to $3.25 \mathrm{in})$ in diameter, due to market preference. Some consumers, especially those in Japan, prefer a larger apple, while apples below $5.7 \mathrm{~cm} \mathrm{(2.25} \mathrm{in)} \mathrm{are}$ generally used for making juice and have little fresh market value. The skin of ripe apples is generally red, yellow, green, pink, or russetted although many bi- or tri-colored varieties may be found (Jules et al., 1996). The flesh is generally pale yellowish-white, though pink or yellow flesh is also known (Jules et al., 1996). Apple juice is one of the most common fruit juices in the world, with world production led by China, Poland, the United States, and Germany (USDA, 2005). The nutritional benefits of apple juice are often underestimated. It contains $83.1 \%$ moisture, $9.2 \%$ sugar, $1.87 \%$ protein, $2.0 \mathrm{mg}$ sodium, $8.7 \mathrm{mg}$ potassium, $2.7 \mathrm{mg}$ calcium, $0.22 \mathrm{mg}$ iron, $0.11 \mathrm{mg}$ copper, $5.1 \mathrm{mg}$ phosphorous and 4.5 $\mathrm{mg}$ vitamin C per $100 \mathrm{~g}$ of whole fruit (Zahid et al., 2008). When closely evaluating the composition of apple juice and other apple products, it becomes apparent that the lack of fat, cholesterol and sodium are just a few of the many reasons these products are an important part of a healthful dietary routine. Fruit sugars such as those found in apple products serve as an immediate source of energy and because apple products taste so good, they are readily consumed by infants and children. Apple juice also serves as an excellent means of providing essential fluids to the body and is unlikely to cause allergic reactions. 
Moreover, apple products have a nutrient/calorie ratio superior to many of the alternative snacks being consumed by children and the US Department of Agriculture`s (USDA, 2008) new food pyramid My Pyramid states that $100 \%$ juice can be substituted for other fruits. A recent national survey of pediatric health professionals has confirmed that apple juice is most often recommended as the first juice for infants (USDA, 2008). It is easily accepted and pleasing to infants. Also, since babies love the sweet taste of apple juice, it may help motivate them to use a cup and accept new tastes and foods.

In fact, recent research suggests that it is the antioxidants that are plentiful in apple juice which are responsible for improving cognitive function. Apples are rich source of antioxidants; and researchers reported that one apple packs more cancer-fighting antioxidant capability than a 1,500 mg dose of vitamin C (Zahid et al., 2008). Efforts have been made by technologists all over the world to providing methods of processing tropical fruits and vegetable through pre-processing storage techniques, preparative processes, extraction, pasteurization, packaging and preservations using chemical and natural preservatives (Ihekoronye and Ngoddy, 1985). Literature abounds on fruit crop processing, fruit juice extraction, efficacy of different artificial preservatives in improving the appearance and storage quality, retarding microbial growth in foods and drinks (Nwachukwu et al., 2007; Ogiehor et al., 2008; Onyeagba et al., 2004). Studies showed that the practice of mixing different exotic fruits and/or certain food preservatives positively impact on the flavor and taste of fruit and fruit products (Nwachukwu et al., 2007; Ogiehor et $a l ., 2008)$. Little is however reported in literature on the use of natural food products as preservatives in subsistent food and fruit processing especially in fruit juice extraction. This study was therefore carried out to compare the performance of a synthetic (Sodium benzoate) and selected natural (garlic and ginger) preservatives on the shelf life quality of locally produced apple fruit juice and to determine the effect of these preservatives and temperature on the $\mathrm{pH}$ and microbial load of locally produced apple fruit juice.

\section{MATERIALS AND METHODS}

\section{Collection and Processing of Fruit}

The Garlic bulbs, Ginger rhizomes and mature, ripe healthy Apple fruits we repurchased from different sales point in Uyo metropolis, Akwa Ibom State, Nigeria and transported to the Food Processing and Analytical Laboratory of the Department of Food Science and Technology, University of Uyo, where the research work was carried out. The Apple fruit were washed with distilled water to remove adhering soils, dirt and extraneous materials. The apples were sorted, trimmed, peeled and cut to small pieces before the extraction of juice.

\section{Preparation of Fruit Additive/Preservative}

The ginger rhizomes and garlic bulbs were washed with potable water repeatedly. Their outer covering was peeled off with a sterile knife and then sliced into cutlets and dried using a hot air oven at $65^{\circ} \mathrm{C}$ for $48 \mathrm{~h}$. An electric blender was used to pulverize the dried ginger and garlic bulb into powder.

\section{Production of Apple Juice}

The pieces of apple were introduced into a juice extractor and the juice extracted. The juice was then filtered using clean muslin cloth into sterile conical flasks.

\section{Treatment of Apple Juice with Natural and Chemical Preservatives}

Natural preservative: Exactly $0.5 \mathrm{~g}$ of ginger powder was added into $100 \mathrm{ml}$ of apple juice and $0.5 \mathrm{~g}$ of garlic powder was added into another $100 \mathrm{ml}$ of the apple juice. Similarly, a combination of $0.25 \mathrm{~g}$ of ginger powder and $0.25 \mathrm{~g}$ of garlic powder were measured and added to $100 \mathrm{ml}$ of apple juice. Chemical preservative: $0.05 \% \quad(w / v)$ sodium benzoate (Sigma chemical company) was aseptically added to another $100 \mathrm{ml}$ of apple juice with another $100 \mathrm{ml}$ of apple juice container serving as a control (without preservative).

\section{Storage of Sample}

The apple juice samples with the preservatives were stored at room temperature $\left(28 \pm 2^{\circ} \mathrm{C}\right)$ and refrigeration temperature $\left(4^{\circ} \mathrm{C}\right)$ for 8 days. The room temperature was measured using the Thermo Pro TP55 Digital Hygrometer Indoor Thermometer and the temperature was maintained at $28 \pm 2^{\circ} \mathrm{C}$. The effect of treatment on $\mathrm{pH}$ of apple juice during storage and the effect of treatment on microbial population of apple juice during storage were monitored throughout the duration of storage.

\section{Microbiological Analysis of Fruit Juice Determination of microbial counts of the juice} The number of microorganisms present in the fruit juice were determined using the spread plate count method. Nutrient Agar was used for the enumeration of total aerobic bacteria while potato dextrose agar was used for fungal count. The agars were prepared according to the manufacturer's instruction. The fruit juice sample were serially diluted up to the $5^{\text {th }}$ dilution and the agar was allowed to cool to $15^{\circ} \mathrm{C}$. Each experiment was carried out in duplicates. Exactly $0.1 \mathrm{ml}$ of each of the dilution was aseptically introduced into sterile petri dishes using spread plate technique. The plates were inverted and incubated at $37^{\circ} \mathrm{C}$ for $24-48 \mathrm{hrs}$ for bacterial count and at $25^{\circ} \mathrm{C}$ for 3-5 days for fungal count. Colonies that developed on the plates were counted and expressed as colony forming units per milliliter $\left(\mathrm{CFU} \mathrm{mL}^{-1}\right)$ of the sample. The process was repeated at two days intervals for 8 days (Cheesbrough, 2000). 


\section{Determination of $\mathbf{p H}$}

The $\mathrm{pH}$ of each group of containers with the different treatment was determined with a ph meter (Jenway pH meter, Model 3310) for the storage period ( 8 days), at two days interval from the first day. Ten milliliters of the juice was dispensed into a beaker and the $\mathrm{pH}$ was determined with a previously standardized $\mathrm{pH}$ meter. The $\mathrm{pH}$ meter was calibrated using phosphate buffer of $\mathrm{pH} 4.0$ and 7.0 (AOAC, 2005).

\section{RESULTS AND DISCUSSION \\ Microbial Population Counts}

The effect of different treatments and temperature on the microbial load of the apple juice throughout the period of storage is shown in Figures 1-4. The addition of the preservatives helps to reduce the bacterial load in all juice sample treatments stored at $4^{\circ} \mathrm{C}$ and room temperature $\left(28 \pm 2^{\circ} \mathrm{C}\right)$ with juice and sodium benzoate showing the highest reduction from $4.0 \times 10^{4}$ to $8.0 \times 10^{3} \mathrm{cfu} \mathrm{ml}^{-1}$ and $4.0 \times 10^{4}$ to $7.0 \times$ $10^{3} \mathrm{cfu} \mathrm{ml}^{-1}$ for juice stored at $4^{\circ} \mathrm{C}$ and room temperature respectively. There was no increase in the bacterial load for control samples stored at $4^{\circ} \mathrm{C}$ but increase in the sample stored at room temperature $4.2 \times 10^{4}$ to $4.0 \times 10^{4} \mathrm{cfu} \mathrm{ml}^{-1}$ and $4.1 \times$ $10^{4}$ to $6.0 \times 10^{4} \mathrm{cfu} \mathrm{ml}^{-1}$. The same trend was seen in the fungal load with juice treated with sodium benzoate having the highest reduction $1.0 \times 10^{4}$ to $2.0 \times 10^{3} \mathrm{cfu} \mathrm{ml}^{-1}$ and $1.2 \times 10^{4}$ to $3.0 \times 10^{3} \mathrm{cfu} \mathrm{ml}^{-1}$ for samples stored at $4^{\circ} \mathrm{C}$ and room temperature respectively as compared to other treatments with the control sample having an increase in the fungal load $1.2 \times 10^{4}$ to $2.2 \times 10^{4} \mathrm{cfu} \mathrm{ml}^{-1}$ for the period of storage.

\section{Effect of Preservatives on pH during Storage}

Figures 5 and 6 shows the effect of the different treatments on the $\mathrm{pH}$ of apple juice. $\mathrm{pH}$ of juice sample stored at $4^{\circ} \mathrm{C}$ with ginger ranges between 4.97 to 5.16 , juice with garlic ranges between 4.50 to 4.89. The juice with combination of ginger/garlic ranges between 4.74 to 4.91 , juice with sodium benzoate ranges between 4.57 to 4.88 while juice alone (control) ranges between 4.43 to 4.81 . For juice samples stored at room temperature $\left(28 \pm 2^{\circ} \mathrm{C}\right)$, the $\mathrm{pH}$ ranges between 4.67 to $4.97,4.97$ to 5.16 , 4.61 to $4.89,4.67$ to 4.91 and 4.53 to 4.88 for control sample, juice and ginger, juice and garlic, juice and ginger/garlic, juice and sodium benzoate respectively.

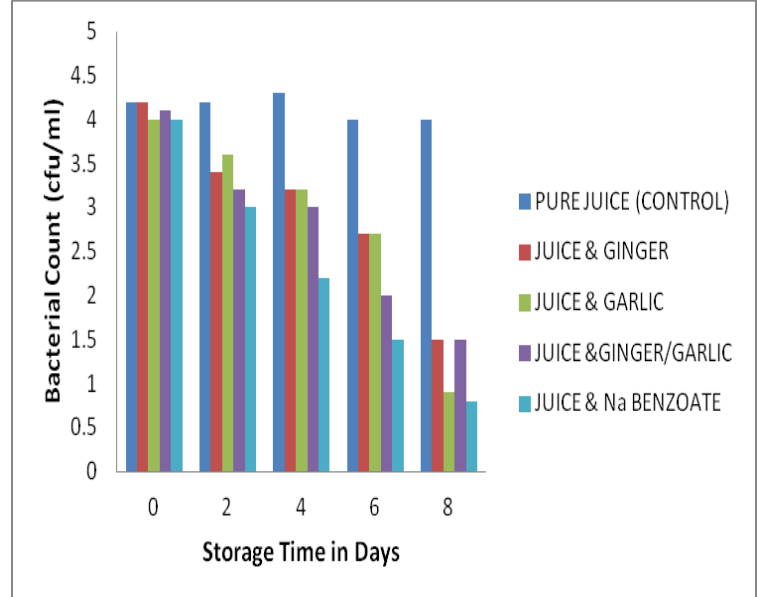

Figure 1: Effect of preservatives on the bacterial count $\left(10^{4}\right)$ at $4^{\circ} \mathrm{C}$ during storage

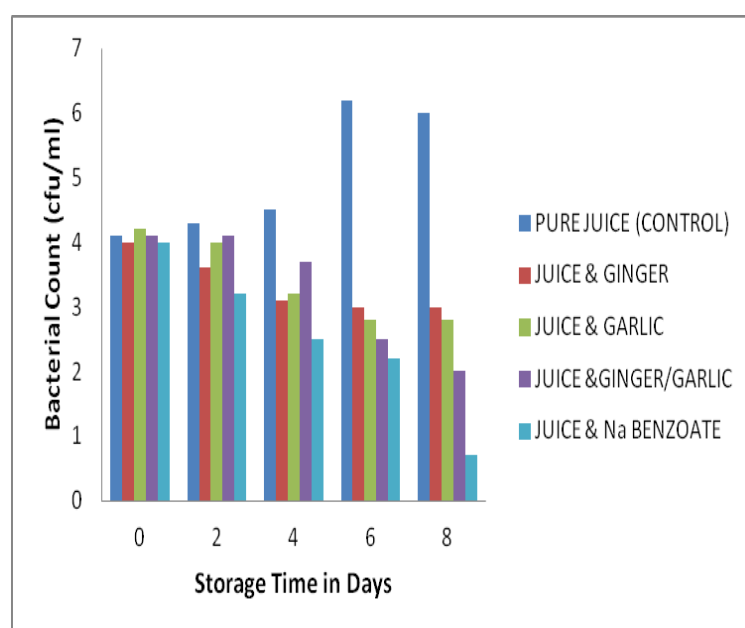

Figure 2: Effect of preservatives on the bacterial count $\left(10^{4}\right)$ at $\left(28 \pm 2^{\circ} \mathrm{C}\right)$ during storage

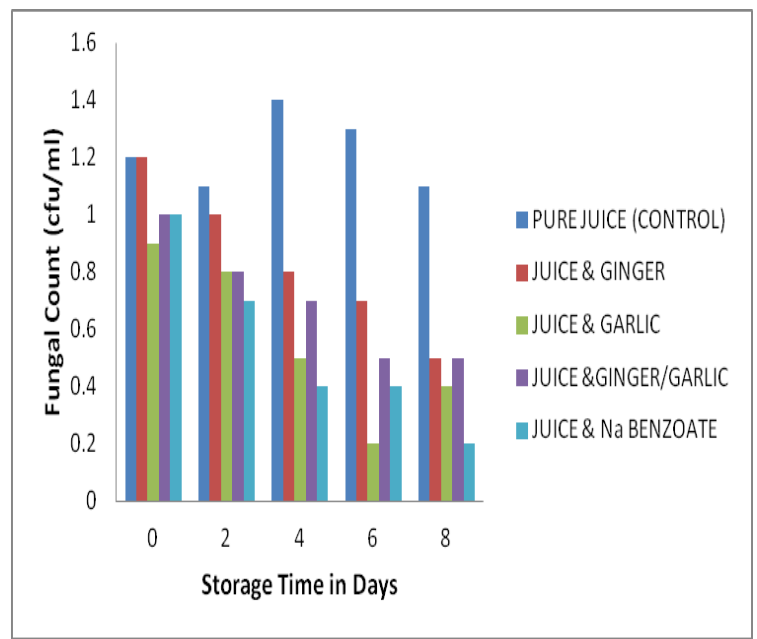

Figure 3: Effect of preservatives on the fungal count $\left(10^{4}\right)$ at $4^{\mathrm{O}} \mathrm{C}$ during storage 


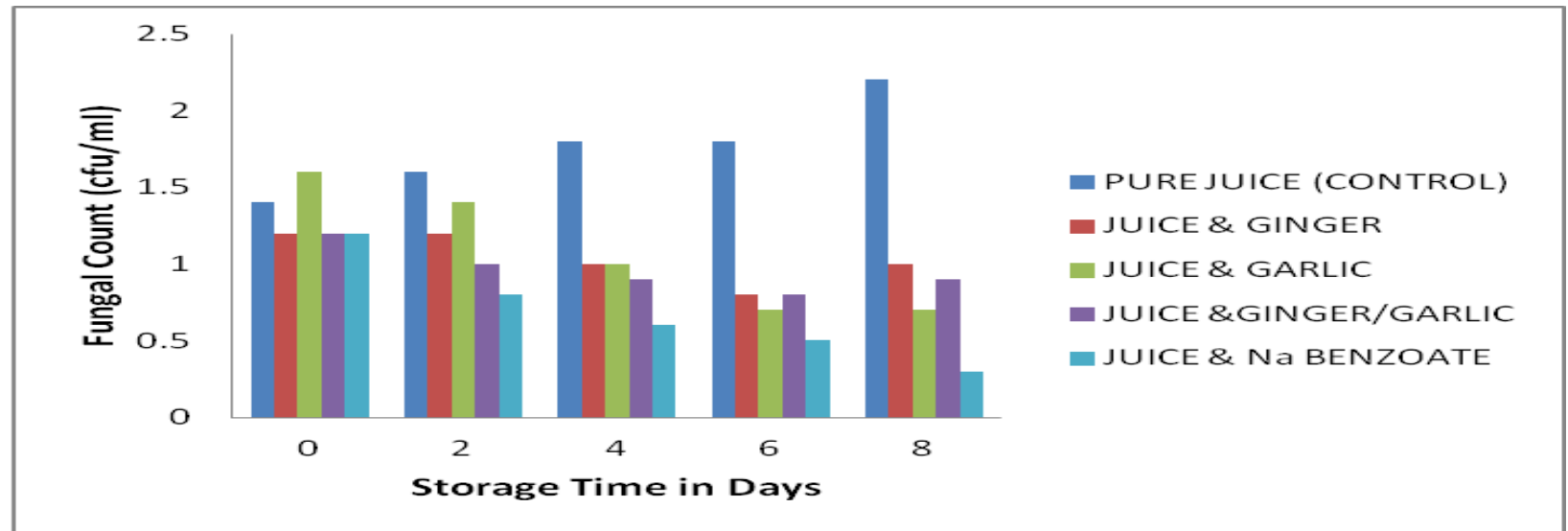

Figure 4: Effect of preservatives on the fungal count $\left(10^{4}\right)$ at $\left(28 \pm 2^{\circ} \mathrm{C}\right)$ during storage

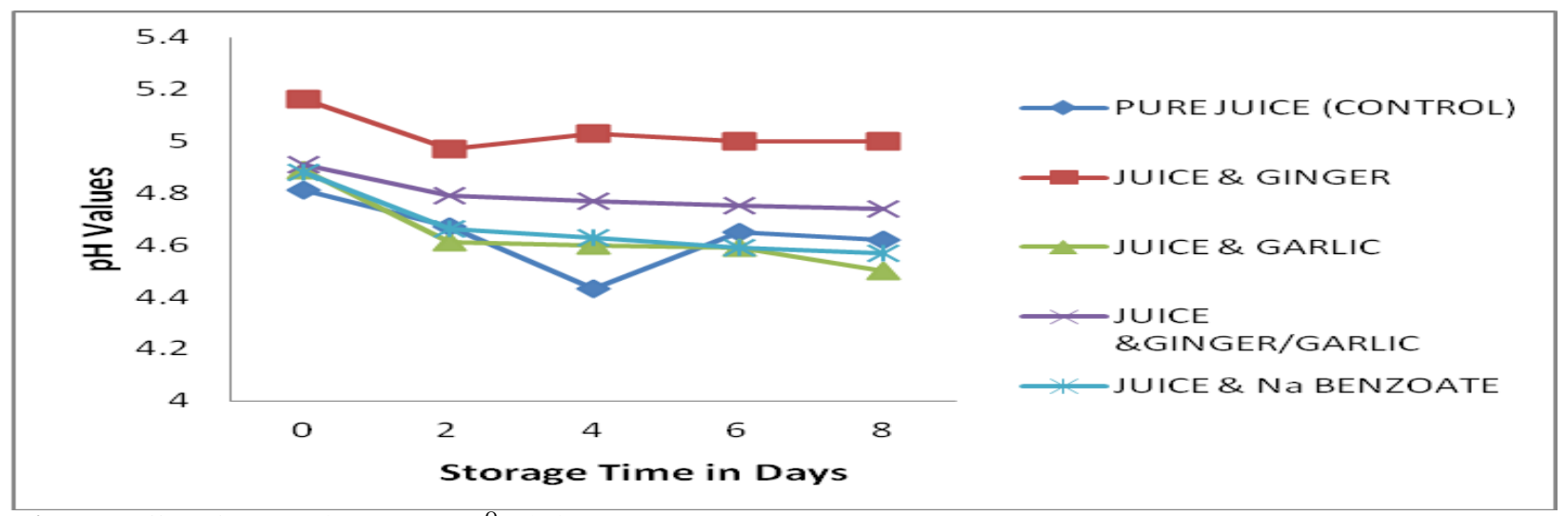

Figure 5: Effect of preservatives on $\mathrm{pH}$ at $4^{\circ} \mathrm{C}$ during storage

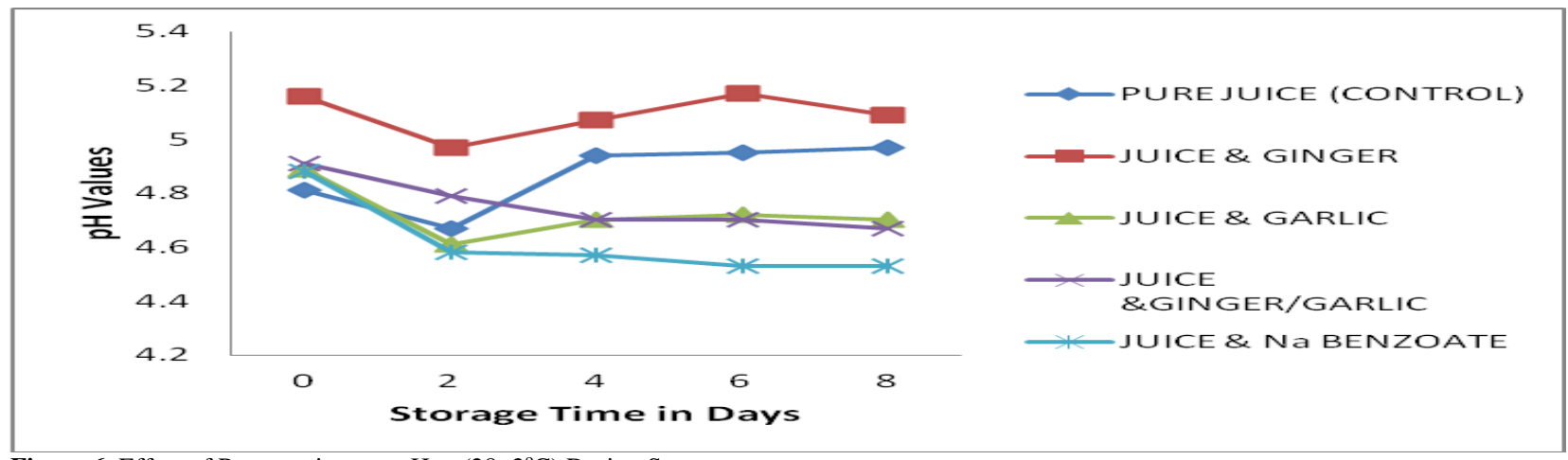

Figure 6: Effect of Preservatives on $\mathrm{pH}$ at $\left(28 \pm 2^{\circ} \mathrm{C}\right)$ During Storage

Treatment Formulation Table

\begin{tabular}{ll} 
Treatment Formulation Table \\
\hline Sample & Treatment \\
\hline Pure juice & No treatment (control) \\
Juice+ ginger & $0.5 \mathrm{~g}$ ginger \\
Juice+ garlic & $0.5 \mathrm{~g}$ garlic \\
Juice+ ginger/garlic & $0.25 \mathrm{~g}$ ginger $+0.25 \mathrm{~g}$ garlic \\
Juice + sodium benzoate & $0.05 \%(\mathrm{w} / \mathrm{v})$ sodium benzoate \\
\hline All the treatments were carried out in duplicates
\end{tabular}

The microbial load data obtained from the apple fruit juice suggest that both the natural preservatives (ginger, garlic and their mixture) and the synthetic sodium benzoate preservative were effective in prolonging the shelf-life of the apple fruit juice with the sodium benzoate showing a better bacteriostatic and fungistatic performance at both temperatures of storage. The reason for this observation may be attributed to the insolubility of natural preservatives used for the study. The use of some chemical preservatives such as sorbate and benzoate to improve the shelf life of drinks has been reported (Dougheri et al., 2007; Nwachukwu and Ezeigbo, 2013). According to Krebs et al. (2006), Sodium benzoate is a bacteriostatic and 
fungistatic preservative underneath acidic environment and is mostly used in acidic foods like salad dressings (vinegar), carbonated munchies (carbonic acid) and condiments. The inability of the apple juice to stay for a long period without preservatives could synergize the nutrient status of the fruit juices creating the appropriate food base for the colonization by microorganisms (Andargie et al., 2008; Fasolin and Cunha, 2012). Ginger (Zingiber officinale) and garlic (Allium sativum) are traditionally used as spices in food preparation but also have both antioxidant and antimicrobial properties (Kolapo et al., 2007). Ginger was reported to have bactericidal effect against Escherichia coli and Streptococcus (Smith-Palmer et al., 1998). Benzoates are preferable in the preservation of fruit juices due to the solubility of their salts. Benzoates are used at low temperatures to extend the shelf-life of minimally processed juices (Uma et al., 2011). The irwide usage is due to their broad-spectrum activity against some microorganisms, as well as their non-alteration of food flavor. The reduction in the microbial loads over storage period in juice treated with both natural preservatives and the synthetic preservative may be attributed to the antimicrobial and phytochemical properties of the preservatives and apple juice respectively as antimicrobials can effectively extend the shelf-life of fruit products (Tagoe et al., 2010; Ukwo et al., 2010). The results of this investigation also revealed that untreated apple juice (control) had a higher level microbial load during the period of storage. This could probably be due to the microbial activities favored by the absence of refrigeration in the juice stored at room temperature and preservatives. This finding therefore suggests that the addition of these preservatives to apple juice might prolong the shelf-life of the juice.

The fruit preservation performance of these phytogens showed no difference in the reduction of the microbial loads in fruit juices treated with ginger, garlic and mixture of both respectively. The $\mathrm{pH}$ results (figures 5 and 6) showed a gradual acidic inclination for the period of storage in samples stored at room temperature and $4^{\circ} \mathrm{C}$ except for juice treated with ginger. This is in consonance with the reports of Dennis et al. (2013) and Fleet, (2003) that the addition of ginger and garlic moves the $\mathrm{pH}$ towards acidity and also reduces the microbial load profile in the fruit juice. Environmental factors, activities of microorganisms together with the incomplete dissolution of the natural preservatives may also alter the $\mathrm{pH}$ of the juice during storage (Ukwo et al., 2010). The excellent keeping quality of fruits and soft drinks is influenced by low $\mathrm{pH}$ (Bates et al., 2001). The near anaerobic condition of the study may have favored the early appearance of bacteria species and the late emergence of fungi isolates as equally observed in the microbiological results from the work of Dennis et al. (2013) on a homemade soursop (Annona muricata L.) fruit juice.

\section{CONCLUSION}

Home-made non-commercial juices that are processed by using mechanical or electrical juice extractor, squeezing, macerating or aqueous/solvent extractions, with or without the application of heat have short shelf life and low organoleptic property as found in the present study. The findings of this study generally indicate that combination of chemical and natural preservation together with refrigeration is suitable for preservation of apple juice for a long time. These methods considerably decreased the microbial count. Since these methods are simple, inexpensive and convenient, they can be adopted for industrial use in the processing and preservation of apple juice. The utilization of the preserved juice should be encouraged as health/therapeutic drink. Above all, preservation of apple juice is important because of the seasonality of its production which makes it abundantly available during its season and scarce during off season. Chemical preservatives can be replaced with natural preservatives such as ginger and garlic.

\section{REFERENCES}

Andargie G., Kassu A., Moges F., Tiruneh M. and Huruy K. (2008) Prevalence of bacteria and intestinal parasites among food-handlers in Gondar Town, Northwest Ethiopia. Journal of Health and Population Nutrition, 26, 451-455

AOAC. (2005). Official Methods of Analysis of AOAC International. 18th Edn., AOAC International, Gaithersburg, MD., USA., ISBN-13: 9780935584752

Bates R.P., Morris J.R. and Crandall P.G. (2001). Principles and practice of small- and medium-scale fruit juice processing. FAO Agricultural Service Bulletin, 146, 1-221

Cheesbrough M. (2000). District Laboratory Practice in Tropical Countries, Part 2. Cambridge University Press, pp. 52-70

Dennis E.V., Omorefosa O.O. and Juliet N.A. (2013). The effect of garlic and ginger phytogenics on the shelf life and microbial contents of homemade soursop (Annonamuricata L) fruit juice. International Journal of the Nigerian Society for Experimental Biology, 25 (2), 31-38

Dougheri J.H., Alabi G. and Elmahmood A.M. (2007). Effect of some chemical preservatives on the shelflife of Zobo drink. African Journal of Microbiology Research, 2, 37-41

FAO (2015). FAO production data, FAO. Retrieved 2 July 2015

Fasolin L.H. and Cunha R.L. (2012). Soursop juice stabilized with soy fractions: a rheological approach. Ciênc. Tecnol. Campinas, 32, 558-567

Fleet GH (2003) Yeast interactions and wine flavour. Int. Journal of Food Microbiology, 86, 11-22 
Germplasm Resources Information Network (GRIN). Retrieved 29 January 2012."Pyrusmalus L."

Germplasm Resources Information Network (GRIN). Retrieved 4 January 2012."Maluspumilaauct."

Ihekoronye A.T. and Ngoddy P.O. (1985). Integrated Food Science and Technology for the Tropics. Macmillan Publishers Limited, London, UK., ISBN13: 9780333388839 , pp: 167, 171-179

Jules J., James N., Cummins S., Brown K. and Minou H. (1996). "Chapter 1: Apples". In Jules Janick and James N. Moore. Fruit Breeding, Volume I: Tree and Tropical Fruits (PDF). John Wiley \& Sons, Inc. p. 9. ISBN 0-471-31014-X

Kolapo A.L., Popoola T.O.S., Sanni M.O and Afolabi R.O. (2007). Preservation of soybean daddawa condiment with dichloromethane extract of ginger. Research Journal of Microbiology; 6, 13-18.

Krebs H.A., Wiggins D., Stubbs M., Sols A. and Bedoya F. (2006). Studies on the mechanism of the antifungal action of benzoate. Journal of Biochemistry, 214, 657-63

Nwachukwu E., Onovo O.M. and Ezema C.F. (2007). Effect of lime juice on the bacterial quality of Zobo drinks locally produced in Nigeria. Research Journal of Microbiology, 2, 787-790

Nwachukwu E. and Ezeigbo C.G. (2013). Changes in the microbial population of pasteurized soursop juice treated with benzoate and lime during storage. African Journal of Microbiology Research, 7 (31), 3992-3995

Ogiehor S.I., Nwafor O.E. and Owhe-Ureghe U.B. (2008). Changes in the quality of zobo beverages produced from Hibiscus sabdariffa (Linn.) Roselle and the effects of extract of ginger alone or in combination with refrigeration. African Journal of Biotechnology, 7, 1176-1180
Onyeagba RA, Ugbogu OC, Okeke, CU and Iroakazi O (2004) Studies on the antimicrobial effects of garlic (Allium sativumLinn), ginger (Zingiber officinale Roscoe) and lime (Citrus aurantifolia Linn). African Journal of Biotechnology 3, 552-554.

Tagoe D, Baidoo S, Dadzie I, Kangah V and Nyarko H (2010). A comparison of the antimicrobial (antifungal) properties of garlic, ginger and lime on Aspergillus flavus, Aspergillus niger and Cladosporium herbarium using organic and waterbased extraction methods. Internet Journal of Tropical Medicine 7 (1), doi:10.5580/1099.

Ukwo SP, Ezeama, CF and Ndaeyo NU (2010) Growth of different yeast strain during fermentation of soursop (Annonamuricata) juice as influenced by acetic acid bacteria. Nature, 5, 23-24

Uma T, Rama RV, Khasim BS (2011). Preservation and shelf life extension of cashew apple juice. Internet $J$. Food Safety, 13, 275-280.

United States Department of Agriculture, USDA (2008). New Food Pyramid: My pyramid. Pyramid/Fruits/Tips to fruits. http://www.mypyramid.gov/pyramid/fruits tips.html.

United States Department of Agriculture, USDA (2005). Foreign Agricultural Service. World Apple Juice Situation. 2004-2005

Smith-Palmer A., Stewart J. and Fyte L. (1998). Antimicrobial properties of plant essential oil against five important food borne pathogen, Lettersin Food Microbiology, 26, 112-118

ZahidM., Alam Z., Mohammad A., Nizakat B., Amal B. and Ihsanullah I. (2008). Effect of pasteurization and chemical preservatives on the quality and shelf stability of apple juice. American Journal of Food Technology, 3, 147-153 